10

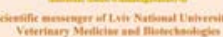

(2)

27

10)

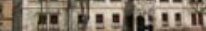

yong

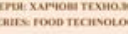

Том 21 Nis 91

2019
Науковий вісник Львівського національного університету ветеринарної медицини та біотехнодогій імені С.3. Гжицького. Серія: Харчові технології

Scientific Messenger of Lviv National University of Veterinary Medicine and Biotechnologies.

Series: Food Technologies

ISSN 2519-268X print

https://nvlvet.com.ua/index.php/food

doi: $10.32718 /$ nvlvet-f9112

UDC 637.354

\title{
Research of properties of traditional Carpathian cheeses
}

\author{
O.Y. Tsisaryk, I.M. Slyvka, L.Y. Musiy
}

Stepan Gzhytskyi National University of Veterinary Medicine and Biotechnologies Lviv, Ukraine

Article info

Received 22.01.2019

Received in revised form 21.02 .2019

Accepted 22.02.2019

Stepan Gzhytskyi National University of Veterinary Medicine and Biotechnologies Lviv, Pekarska Str., 50, Lviv, 79010, Ukraine.

Tel.: +38-067-600-11-04: $+38-097-986-15-44$ +38-098-132-31-63

E-mail: tsisaryk_o@yahoo.com, slyvka.88@ukr.net. musiyluba@ukr.net
Tsisaryk, O.Y., Slyvka, I.M., \& Musiy, L.Y. (2019). Research of properties of traditional Carpathian cheeses. Scientific Messenger of Lviv National University of Veterinary Medicine and Biotechnologies. Series: Food Technologies, 21(91), 69-78. doi: 10.32718/nvlvet-f9112

The purpose of the work was to investigate the organoleptic, physico-chemical and microbiological indices of traditional Carpathian cheeses, in particular, brynza, butz and vurda, made directly on the mountain valleys with traditional technology in Rakhiv district of the Transcarpathian region. Of 16 samples of cheese, 13 samples were cheese butz (samples 1, 2, 3, 5, 6, 7, 8, 9, 10,11, 12, 13, 15); vurda cheese (samples 4 and 16) and cheese of brynza a year ago (sample 14). Experimental studies of organoleptic, physicochemical and microbiological parameters of cheese samples were carried out in the laboratory of the milk and milk products department and in the department of biotechnology at Rzeszow University (Poland). In samples of cheese, organoleptic parameters were studied in accordance with GOST 7616-85; active acidity - by potentiometric method using the $\mathrm{pH}$ meter of the ARN-9 brand; titrated acidity - titrarily (in degrees Turner) according to GOST 3624-67. The mass fraction of salt in the cheese was determined by titration of the extract with nitric oxide silver (GOST 3627-81). The detection of bacteria of the genus Staphylococcus aureus was determined by sowing on a solid Gissa with mannitol, with further detection and confirmation of the belonging of the grown colonies to Staphylococcus aureus (GOST 30347-97). The detection of bacteria of the genus Salmonella was determined by sowing on the Endo solid medium (GOST 31659-2012). The bacteria of the intestinal stem group were determined by sowing on a Kessler liquid medium (GOST 922584). Cultivation of microorganisms was carried out at temperature $+37^{\circ} \mathrm{C}$ for $48 \mathrm{~h}$. According to researches of organoleptic parameters of cheeses it was found that samples of cheese butz were characterized by sour milk, and samples of 3 and 5 sour taste and aroma, a dense humus consistency and from gray to white color. Figure - with single small and large bodies of irregular shape. According to studies of organoleptic parameters of cheese, the taste and aroma of the product should be given - light sour milk, salted, which is confirmed by the salt content - 4.6\%. Consistency was crumbly, the color was yellow. Samples of cheese vurda were characterized by delicate butter, sour milk taste and smell, paste, crumbly consistency and white color. Analyzing the acidity of butz cheese it was that it was high particularly in samples 3, 8 and 14, which was reflected in organoleptic parameters. In the samples of vurda titrated acidity was $75^{\circ} \mathrm{T}$ in sample 4 ( $p H$ 5.7) and $16^{\circ} \mathrm{T}$ in sample 16 ( $\mathrm{pH}$ 6.4), while brynza was characterized by the highest acidity $-260^{\circ} \mathrm{T}$ ( $p H$ 4.9). According to microbiological parameters, all specimens were characterized by the presence of pathogenic microflora. In particular, 1, 3, 5-9, 11-15 samples showed Staphylococcus aureus, 10 sample of Staphylococcus epidermis, 2 sample of bacteria of the genus Salmonella, 16 sample of Enterobacter aerogenes, and 4 samples of mold.

Key words: brynza, butz, vurda, organoleptic parameters, physico-chemical parameters, microbiological parameters, Staphylococcus aureus, Salmonella.

\section{Дослідження властивостей традиційних карпатських сирів}

\author{
О.Й. Цісарик, І.М. Сливка, Л.Я. Мусій
}

Львівський національний університет ветеринарної медицини та біотехнологій імені С.3. Гжицького, м. Львів, Україна

Метою роботи було дослідити органолептичні, фізико-хімічні та мікробіологічні показники традиційних карпатських сирів, зокрема бринзи, буиу та вурди, виготовлених безпосередньо на полонинах за традиційною технологією у Рахівському районі Зака- 
рпатської області. Із 16 зразків сиру 13 зразків - сир буи (зразки 1, 2, 3, 5, 6, 7, 8, 9, 10, 11, 12, 13, 15); сир вурда (зразки 4 і 16) та сир бринза річної витримки (зразок 14). Експериментальні дослідження органолептичних, фізико-хімічних та мікробіологічних показників зразків сиру проводилися у лабораторії кафедри технології молока і молочних продуктів та у відділі біотехнології Жешівського університету (Польща). У зразках сиру досліджували органолептичні показники згідно з ГОСТ 7616-85; активну кислотність - потенціометричним методом за допомогою рН-метра марки АРН-9; титровану кислотність - титрометрично (у градусах Тернера) згідно з ГОСТ 3624-67. Масову частку солі у сирі визначали методом титрування екстракту азотнокислим сріблом (ГОСТ 3627-81). Виявлення бактерій роду Staphylocoсcus aureus визначали шляхом посіву на тверде середовище Гісса з маннітом з подальшим виявленням та підтвердженням належності вирослих колоній до Staphylococcus aureus (ГОСТ 30347-97). Виявлення бактерій роду Salmonella визначали шляхом посіву на тверде середовище Ендо (ГОСТ 31659-2012). Бактерії групи кишкової палички визначали посівом на рідке середовище Кесслера (ГОСТ 9225-84). Культивування мікроорганізмів здійснювали при температурі $+37{ }^{\circ} \mathrm{C}$ протягом 48 год. Згідно з дослідженнями органолептичних показників сирів встановлено, ияо зразки сиру буиу характеризувалися кисломолочним, а зразки 3 і 5 кислим смаком і ароматом, щуільною гумоподібною консистениією та кольором від сірого до білого. Рисунок - з поодинокими дрібними та великими вічками неправильної форми. Згідно з дослідженнями органолептичних показників бринзи, слід віддати належне смаку і аромату продукту - легкий кисломолочний, солений, ицо підтверджується вмістом солі-4,6\%. Консистенція розсипчаста, колір жовтий. Зразки сиру вурда характеризувалися ніжним вериковим, кисломолочним смаком та запахом, пастоподібною, розсипчастою консистенцією та білим кольором. Аналізуючи кислотність сиру буи, спостерігали, шуо вона була високою зокрема у зразках 3, 8 та 14, шуо позначалося на органолептичних показниках. У зразках вурди титрована кислотність була $75^{\circ} \mathrm{T}$ у зразку 4 (рН 5,7) та $16^{\circ} \mathrm{T}$ у зразку 16 (рН 6,4), тимчасом як бринза характеризувалася найвищою кислотністю - $260^{\circ} \mathrm{T}(\mathrm{pH} 4,9)$. За мікробіологічними показниками всі зразки характеризувалися наявністю патогенної мікрофлори. Зокрема у зразках 1,3, 5-9, 11-15 було виявлено Staphylococcus aureus, y зразку 10 - Staphylococcus еріdermis, у зразку 2 - бактерій роду Salmonella, у зразку 16 - Enterobacter aerogenеs та у зразку 4-nлісень.

Ключові слова: бринза, буи, вурда, органолептичні показники, фізичико-хімічні показники, мікробіологічні показники, Staphylococcus aureus, Salmonella.

\section{Вступ}

Історія сиру почалася близько 4 тисяч років тому в арабських країнах, пізніше сир прийшов до Європи. Асортимент сучасних сирів дуже різноманітний. Вони відрізняються один від одного за технологічними параметрами, мікробіологічними і біохімічними процесами під час виготовлення, хімічним складом, формою та масою, а наявність великої кількості найменувань пов'язують з історичними, національними та географічними особливостями зародження сирів у різних країнах і в різних народів (Gomez et al., 1999; Irigoyen et al., 2002).

Серед сирів особливе місце займають м'які сири. В результаті біохімічних процесів, які відбуваються під час визрівання сирів, в них утворюється велика кількість пептидів і амінокислот за короткіші терміни порівняно $з$ напівтвердими та твердими сирами, що дозволяє відносити м'які сири до дієтичних продуктів. Широкий смаковий діапазон м'яких сирів повністю задовольняє потреби споживачів 3 будь-якими вподобаннями (Silva et al., 2012).

В Україні особливо швидко зростає інтерес до розсольних сирів. Сьогодні це один із сегментів, який найбільш динамічно розвивається і займає особливу нішу в сироробній галузі. Зокрема, популярними в Україні є сир бринза, буц та вурда, які виготовляють у Карпатському регіоні. Бринза - це найпопулярніший вид сиру в Карпатах (Slyvka et al., 2018). Кому пощастило бодай раз скуштувати цей унікальний концентрат карпатського дару природи, ніколи не забуде ніжний присмак полонинських делікатесів, приправлених запахом ватри, прянощами трав та смерекового лісу. Заслуговує на увагу Фестиваль-ярмарок "Гуцульська бриндзя”, який щоосені проводиться в Україні на Закарпатті протягом останніх років. Фестиваль розрахований, передусім, на туристів, він сприяє відродженню вівчарства і приваблює в регіон інвесторів (Vyshnevska \& Tsehelnyk, 2012; Tsisaryk et al., 2014). Карпати вважаються “осередком” справжніх сирова- рів. Асоціація виробників традиційних карпатських високогірних сирів провела заходи для промоції потенційного першого українського географічного зазначення на продукти харчування, визнаного в СС. Ним уже наступної весни може стати гуцульська овеча бриндзя - це буде перший продукт із переліку українських, який має шанси отримати географічне зазначення.

Традиційно бринзу та буц виготовляють із сирого овечого молока у приватних господарствах. У процесі виготовлення сирів із сирого молока бактеріальні культури не додаються, тому під час дозрівання природна мікрофлора переважає над іншими групами мікроорганізмів (Slyvka et al., 2017).

Приготування бринзи - справжне священнодійство. Споконвіку незмінними залишаються основні компоненти бринзи - свіже овече молоко та так званий “кляг”, який отримують зі шлунку молочного ягняти. Технологія виготовлення бринзи передбачає зсідання нагрітого молока з “клягом", 3 подальшим його збиванням так званим дерев'яним “жбаталовом” та формуванням соковитих грудочок, які поміщають в чисте полотно та підвішують, щоб стекла сироватка (Turynskyi et al., 2000).

Отриманий “півфабрикат” бринзи - будз - вже готовий до споживання. Копчений будз має щільну, коричневу скоринку та зберігається в колибах, де палять ватру. А процес приготування бринзи триває будз витримують певний час в теплому місці, надалі солять, перетирають руками, перекладають у дерев'яну “бербеницю” та витримують під гнітом близько місяця (Basiuk, 2017). Готова бринза може зберігатися до двох років. Цей надзвичайно популярний в горах продукт додають до безлічі традиційних гуцульських страв - бануша, кулеші, вареників, книшів. Бринзу можна їсти з грибами та шкварками, з картоплею та кислим молоком - споживання смачного, дієтичного продукту не має обмежень. Сам процес приготування бринзи є надзвичайно цікавим та навіть чимось магічним. Адже полонини та плаї, на яких 
розташовані вівчарські колиби - де саме народжується гуцульський сир, притягують до себе не лише гурманів, а й звичайних туристів, людей, яким карпатський колорит, звичаї та обряди горян стануть яскравою згадкою про дивовижну подорож Українськими Карпатами (Halukh et al., 2010).

Вурда - ще один різновид овечого сиру, який відрізняється м'якою консистенцією та ніжним смаком. Виготовляється вурда 3 сироватки, що залишається після приготування бринзи, із додаванням свіжого овечого молока методом нагрівання, при якому утворюється сирний згусток. Задля соковитості вурди сироватку не відпресовують повністю. Вурду можна споживати як самостійно, так і додавати у різні страви та випічку. Аналогом вурди в Свропі є сир рікотта або брюєль (Bilyk \& Dronyk, 2014; Bilyk et al., 2017).

Сучасний ринок висуває високі вимоги щодо якості харчової продукції, зокрема молочних продуктів. Під якістю харчового продукту розуміють ступінь досконалості властивостей та характерних рис харчового продукту, які здатні задовольнити потреби та побажання тих, хто споживає або використовує цей харчовий продукт. Найбільш прийнятним способом визначення сукупності властивостей продукції є встановлення вимог до неї у нормативних документах технічних умовах, стандартах тощо (Yashkina \& Makovetska, 2017). Молочні продукти повинні відповідати не тільки смаковим уподобанням споживачів, але й бути корисними та безпечними до споживання. Для популяризації м'яких сичужних сирів вітчизняного виробництва необхідно найперше підвищити їхню якість, асортимент та конкурентоспроможність як на внутрішньому, так і на зовнішньому ринку (Milci et al., 2005).

Метою роботи було дослідити властивості та показники якості традиційних карпатських сирів, зокрема бринзи, буцу та вурди, виготовлених на полонинах за традиційною технологією у Рахівському районі Закарпатської області. Рахівський район розташований у найбільш високогірній частині Українських Карпат. На полонинах району гуцули випасають овець, осередками випасу є колиби, де від травня до жовтня живуть і виготовляють сир.

\section{Матеріал і методи досліджень}

У роботі проаналізовано 16 зразків овечого сиру бринза, буцу та вурди, виготовлені на різних полонинах у Рахівському районі. Проведено органолептичну оцінку зразків сиру, досліджено їхні фізико-хімічні та мікробіологічні показники. Із 16 зразків сиру 13 зразків - сир буц (зразки 1, 2, 3, 5, 6, 7, 8, 9, 10, 11, $12,13,15)$; сир вурда (зразки 4 і 16) та сир бринза річної витримки (зразок 14).

Експериментальні дослідження органолептичних, фізико-хімічних та мікробіологічних показників зразків сиру проводилися у лабораторії кафедри технології молока і молочних продуктів Львівського національного університету ветеринарної медицини та біотехнологій імені С.3. Гжицького та у відділі біотехнології Жешівського університету (Польща).
Аналіз готового продукту проводили згідно 3 ДСТУ 7065:2009 (Бринза. Загальні технічні умови). До уваги брали органолептичні, фізичні та мікробіологічні показники виготовленої бринзи. Мікробіологічні показники обмежені лише вимогами щодо безпечності споживання сирів. Вони включають дослідження на наявність бактерій групи кишкової палички (БГКП), бактерій роду Salmonella, Staphylococcus aureus та Listeria monocytogenes.

У зразках сиру досліджували органолептичні показники згідно з ГОСТ 7616-85; активну кислотність потенціометричним методом за допомогою $\mathrm{pH}$-метра марки АРН-9; титровану кислотність - титрометрично (у градусах Тернера) згідно з ГОСТ 3624-67. Масову частку солі у сирі визначали методом титрування екстракту азотнокислим сріблом (ГОСТ 3627-81).

Підготовку проб до мікробіологічних аналізів та культивування мікроорганізмів проводили згідно 3 вимогами існуючих нормативних документів та за загальноприйнятими методиками: Молоко і молочні продукти. Підготовка зразків і розведень для мікробіологічних досліджень (IDF 122C:1996, IDT): ДСТУ IDF 122C:2003. Виявлення молочнокислих бактерій проводили методом посіву десятиразових розведень досліджуваного матеріалу на тверде живильне середовище. Для цього 10 г сиру зважували в стерильних умовах, отримували послідовні десятиразові розведення. Виявлення бактерій роду Staphylococcus aureus визначали шляхом посіву на тверде середовище Гісса 3 маннітом 3 подальшим виявленням та підтвердженням належності вирослих колоній до Staphylococcus aureus (ГОСТ 30347-97). Виявлення бактерій роду Salmonella визначали шляхом посіву на тверде середовище Ендо (ГОСТ 31659-2012). Бактерії групи кишкової палички визначали посівом на рідке середовище Кесслера (ГОСТ 9225-84). Культивування мікроорганізмів здійснювали при температурі $+37^{\circ} \mathrm{C}$ протягом 48 год.

\section{Результати та їх обговорення}

При визріванні сирів проходять складні біохімічні перетворення, в результаті яких за певних умов відбувається нагромадження смакових і ароматичних сполук, що зумовлюють специфічний смак і аромат сиру (Milci et al., 2005). Результати дослідження оранолептичних, фізичних та мікробіологічних показників наведено в таблицях 1-16.

Згідно з дослідженнями органолептичних показників сирів зауважимо, що зразки сиру буцу характеризувалися кисломолочним, а зразки 3 і 5 кислим смаком і ароматом, щільною гумоподібною консистенцією та від сірого до білого кольором. Рисунок - 3 поодинокими дрібними та великими вічками неправильної форми. Згідно з дослідженнями органолептичних показників бринзи, варто віддати належне смаку i аромату продукту - легкий кисломолочний, солений, що підтверджується вмістом солі - 4,6\%. Консистенція розсипчаста, колір жовтий. Зразки сиру вурда характеризувалися ніжним вершковим, кисломолочним смаком та запахом, пастоподібною, розсипчастою консистенцією та білим кольором. Аналізуючи кисло- 
тність сиру буц, спостерігали, що вона була високою, зокрема у зразках 3,8 та 14 , що позначалося на органолептичних показниках. У зразках вурди титрована кислотність була $75^{\circ} \mathrm{T}$ у зразку $4(\mathrm{pH} 5,7)$ та $16^{\circ} \mathrm{T}$ у зразку 16 (рН 6,4), тимчасом як бринза характеризувалася найвищою кислотністю - $260^{\circ} \mathrm{T}(\mathrm{pH} 4,9)$. Від кількісного і якісного складу мікрофлори сирого молока великою мірою залежить якість сирів, вироблених 3 нього. За мікробіологічними показниками всі зразки характеризувалися наявністю патогенної мікрофлори. Зокрема у зразках 1, 3, 5-9, 11-15 було виявлено наявність Staphylococcus aureus, у зразку $10-$ Staphylococcus epidermis, у зразку 2 - бактерій роду Salmonella, у зразку 16 - Enterobacter aerogenes та у зразку 4 - плісень. Після вживання харчових продуктів, забруднених $S$. aureus, хворих може становити до 90-100\% (Timchenko, 2017).

\section{Таблиця 1}

Органолептичні, фізико-хімічні та мікробіологічні показники сиру буц (зразок 1)

\begin{tabular}{ll|}
\hline \multicolumn{1}{c}{ Назва показника } & \multicolumn{1}{c|}{ Характеристика } \\
\hline Смак і запах & Чистий, кисломолочний \\
Консистенція & Доволі щільна \\
Рисунок & 3 дрібними поодинокими вічками \\
неправильної форми \\
Колір & Від сірого до білого \\
Зовнішній вигляд & Поверхня чиста, без кірки \\
Активна кислотність, рН & 6,2 \\
Титрована кислотність, ${ }^{\circ} \mathrm{T}$ & 80 \\
Стороння мікрофлора & Наявність Staphylococcus aureus \\
\hline
\end{tabular}

\section{Таблиця 2}

Органолептичні, фізико-хімічні та мікробіологічні показники сиру буц (зразок 2)

\begin{tabular}{ll}
\hline \multicolumn{1}{c}{ Назва показника } & \multicolumn{1}{c|}{ Характеристика } \\
\hline Смак і запах & Кисломолочний, солодкуватий \\
Консистенція & Щільна \\
Рисунок & Вічка поодинокі, малі, майже відсутні \\
Колір & Від світло сірого до білого \\
Зовнішній вигляд & Поверхня чиста, без кірки \\
Активна кислотність, $\mathrm{pH}$ & 6,5 \\
Титрована кислотність, ${ }^{\circ} \mathrm{T}$ & 45 \\
Стороння мікрофлора & Наявність бактерій роду Salmonella \\
\hline
\end{tabular}


Таблиця 3

Органолептичні, фізико-хімічні та мікробіологічні показники сиру буц (зразок 3)

\begin{tabular}{ll}
\hline \multicolumn{1}{c}{ Назва показника } & \multicolumn{1}{c}{ Характеристика } \\
\hline Смак і запах & Кислий \\
Консистенція & щільна, однорідна, ламка, але не крихка \\
Рисунок & Вічок багато, дрібні, неправильної форми \\
Колір & Білий \\
Зовнішній вигляд & Поверхня чиста, без кірки \\
Активна кислотність, рН & 4,9 \\
Титрована кислотність, ${ }^{\circ} \mathrm{T}$ & 248 \\
Стороння мікрофлора & Наявність Staphylococcus aureus \\
\hline
\end{tabular}

\section{Таблиця 4}

Органолептичні, фізико-хімічні та мікробіологічні показники сиру вурда (зразок 4)

\begin{tabular}{ll|}
\hline \multicolumn{1}{c}{ Назва показника } & \multicolumn{1}{c|}{ Характеристика } \\
\hline Смак і запах & Ніжний, вершковий, кисломолочний \\
Консистенція & Пастоподібна, зерниста, розсипчаста \\
Рисунок & - \\
Колір & Білий \\
Зовнішній вигляд & Поверхня чиста, без кірки \\
Активна кислотність, $\mathrm{pH}$ & 5,7 \\
Титрована кислотність, ${ }^{\circ} \mathrm{T}$ & 75 \\
Стороння мікрофлора & Наявність плісені \\
\hline
\end{tabular}

Таблиця 5

Органолептичні, фізико-хімічні та мікробіологічні показники сиру буц (зразок 5)

\begin{tabular}{ll}
\hline \multicolumn{1}{c}{ Назва показника } & \multicolumn{1}{c}{ Характеристика } \\
Смак і запах & Кисломолочний, кислуватий \\
Консистенція & Щільна, ламка, але не крихка великі неправильної форми \\
Рисунок & Білий \\
Колір & Поверхня чиста, без кірки \\
Зовнішній вигляд & 5,4 \\
Активна кислотність, рН & 86 \\
Титрована кислотність, ${ }^{\circ} \mathrm{T}$ & Наявність Staphylococcus aureus \\
Стороння мікрофлора & \\
\hline
\end{tabular}




\section{Таблиця 6}

Органолептичні, фізико-хімічні та мікробіологічні показники сиру буц (зразок 6)

\begin{tabular}{ll}
\hline \multicolumn{1}{c}{ Назва показника } & \multicolumn{1}{c}{ Характеристика } \\
\hline Смак і запах & Кисломолочний \\
Консистенція & Дуже щільна, як сичужний сир \\
Рисунок & Дрібні вічка неправильної форми \\
Колір & Сірий \\
Зовнішній вигляд & Поверхня чиста, без кірки \\
Активна кислотність, $\mathrm{pH}$ & 5,5 \\
Титрована кислотність, ${ }^{\circ} \mathrm{T}$ & 85 \\
Стороння мікрофлора & Наявність Staphylococcus aureus
\end{tabular}

\section{Таблиця 7}

Органолептичні, фізико-хімічні та мікробіологічні показники сиру буц (зразок 7)

\begin{tabular}{ll}
\hline \multicolumn{1}{c}{ Назва показника } & \multicolumn{1}{c}{ Характеристика } \\
\hline Смак і запах & Кисломолочний \\
Консистенція & Щільна, гумоподібна \\
Рисунок & Вічка є, скоріше від стискання \\
Колір & Жовтий \\
Зовнішній вигляд & Без кірки \\
Активна кислотність, $\mathrm{pH}$ & 5,5 \\
Титрована кислотність, ${ }^{\circ} \mathrm{T}$ & 85 \\
Стороння мікрофлора & Наявність Staphylococcus aureus
\end{tabular}

\section{Таблиця 8}

Органолептичні, фізико-хімічні та мікробіологічні показники сиру буц (зразок 8)

\begin{tabular}{ll}
\hline \multicolumn{1}{c}{ Назва показника } & \multicolumn{1}{c}{ Характеристика } \\
\hline Смак і запах & Кисломолочний, помірно кислий \\
Консистенція & $\begin{array}{l}\text { Щільна, але крихка } \\
\text { Наявність великої кількості вічок не- } \\
\text { правильної форми } \\
\text { Рисунок }\end{array}$ \\
Білий \\
Колір & Поверхня чиста, без кірки \\
Зовнішній вигляд & 5,4 \\
Активна кислотність, $\mathrm{pH}$ & 120 \\
Титрована кислотність, ${ }^{\circ} \mathrm{T}$ & Наявність Staphylococcus aureus \\
Стороння мікрофлора &
\end{tabular}




\section{Таблиця 9}

Органолептичні, фізико-хімічні та мікробіологічні показники сиру буц (зразок 9)

\begin{tabular}{ll}
\hline \multicolumn{1}{c}{ Назва показника } & \multicolumn{1}{c}{ Характеристика } \\
\hline Смак і запах & Кисломолоний \\
Консистенція & Щільна, розсипчаста \\
Рисунок & Вічка дрібні, поодинокі \\
Колір & Білий \\
Зовнішній вигляд & Поверхня чиста, без кірки \\
Активна кислотність, рН & 5,4 \\
Титрована кислотність, ${ }^{\circ} \mathrm{T}$ & 180 \\
Стороння мікрофлора & Наявність Staphylococcus aureus \\
\hline
\end{tabular}

\section{Таблиця 10}

Органолептичні, фізико-хімічні та мікробіологічні показники сиру буц (зразок 10)

\begin{tabular}{ll}
\hline \multicolumn{1}{c}{ Назва показника } & \multicolumn{1}{c}{ Характеристика } \\
\hline Смак і запах & Кисломолочний \\
Консистенція & Щільна, гумоподібна \\
Рисунок & Вічка відсутні \\
Колір & Жовтий \\
Зовнішній вигляд & Поверхня чиста, без кірки \\
Активна кислотність, $\mathrm{pH}$ & 5,6 \\
Титрована кислотність, ${ }^{\circ} \mathrm{T}$ & 85 \\
Стороння мікрофлора & Наявність Staphylococcus epidermis \\
\hline
\end{tabular}

\section{Таблиця 11}

Органолептичні, фізико-хімічні та мікробіологічні показники сиру буц (зразок 11)

\begin{tabular}{ll|}
\hline \multicolumn{1}{c}{ Назва показника } & \multicolumn{1}{c}{ Характеристика } \\
\hline Смак і запах & Кисломолочний \\
Консистенція & Щільна, тверда \\
Рисунок & Поодинокі вічка \\
Колір & Жовтий \\
Зовнішній вигляд & Поверхня чиста, без кірки \\
Активна кислотність, $\mathrm{pH}$ & 5,2 \\
Титрована кислотність, ${ }^{\circ} \mathrm{T}$ & 150 \\
Стороння мікрофлора & Наявність Staphylococcus aureus \\
\hline
\end{tabular}


Таблиця 12

Органолептичні, фізико-хімічні та мікробіологічні показники сиру буц (зразок 12)

\begin{tabular}{ll|}
\hline \multicolumn{1}{c}{ Назва показника } & \multicolumn{1}{c|}{ Характеристика } \\
\hline Смак і запах & Кисломолочний \\
Консистенція & Щільна, пластична, гумоподібна \\
Рисунок & Поодинокі дрібні вічка \\
Колір & Жовто-сірий \\
Зовнішній вигляд & Поверхня чиста, без кірки \\
Активна кислотність, $\mathrm{pH}$ & 5,5 \\
Титрована кислотність, ${ }^{\circ} \mathrm{T}$ & 120 \\
Стороння мікрофлора & Наявність Staphylococcus aureus \\
\hline
\end{tabular}

\section{Таблиця 13}

Органолептичні, фізико-хімічні та мікробіологічні показники сиру буц (зразок 13)

\begin{tabular}{ll}
\hline \multicolumn{1}{c|}{ Назва показника } & \multicolumn{1}{c|}{ Характеристика } \\
\hline Смак і запах & Кисломолочний \\
Консистенція & Щільна, пластична, гумоподібна \\
Рисунок & Поодинокі дрібні вічка \\
Колір & Жовто-сірий \\
Зовнішній вигляд & Поверхня чиста, без кірки \\
Активна кислотність, $\mathrm{pH}$ & 5,5 \\
Титрована кислотність, ${ }^{\circ} \mathrm{T}$ & 120 \\
Стороння мікрофлора & Наявність Staphylococcus aureus \\
\hline
\end{tabular}

Таблиця 14

Органолептичні, фізико-хімічні та мікробіологічні показники сиру бринза (зразок 14)

\begin{tabular}{ll}
\hline \multicolumn{1}{c}{ Назва показника } & \multicolumn{1}{c}{ Характеристика } \\
\hline Смак і запах & Солений, характерний для бринзи, \\
гострий & Розсипчаста \\
Консистенція & Вічка відсутні \\
Рисунок & Жовтий \\
Колір & Поверхня чиста, без кірки \\
Зовнішній вигляд & 4,9 \\
Активна кислотність, рН & 260 \\
Титрована кислотність, ${ }^{\circ} \mathrm{T}$ & $4,6 \%$ \\
Вміст $\mathrm{NaCl}$ & Наявність Staphylococcus aureus \\
Стороння мікрофлора &
\end{tabular}


Таблищя 15

Органолептичні, фізико-хімічні та мікробіологічні показники сиру бринза (зразок 15)

\begin{tabular}{ll}
\hline \multicolumn{1}{c}{ Назва показника } & Характеристика \\
\hline Смак і запах & Кисломолочний \\
Консистенція & Гумоподібна, крихка \\
Рисунок & Поодинокі вічка неправильної форми \\
Колір & Білий \\
Зовнішній вигляд & Без кірки \\
Активна кислотність, $\mathrm{pH}$ & 4,8 \\
Титрована кислотність, ${ }^{\circ} \mathrm{T}$ & 180 \\
Стороння мікрофлора & Наявність Staphylococcus aureus \\
\hline
\end{tabular}

Таблиця 16

Органолептичні, фізико-хімічні та мікробіологічні показники сиру вурда (зразок 16)

\begin{tabular}{|c|c|c|}
\hline Назва показника & Характеристика & \\
\hline Смак і запах & $\begin{array}{l}\text { Кисломолочний, виражений присмак } \\
\text { жиропоту вівці }\end{array}$ & \\
\hline Консистенція & Пастоподібна, кремоподібна & \\
\hline Рисунок & - & \\
\hline Колір & Сірий & \\
\hline Зовнішній вигляд & Без кірки & \\
\hline Активна кислотність, $\mathrm{pH}$ & 6,4 & \\
\hline Титрована кислотність, ${ }^{\circ} \mathrm{T}$ & 16 & \\
\hline Стороння мікрофлора & Наявність Enterobacter aerogenes & \\
\hline
\end{tabular}

Наявність у зразках сиру патогенної мікрофлори оцінювали за характером росту на відповідних середовищах. Про присутність бактерій роду Staphylococcus aureus свідчило наявність жовтих колоній і зміна $\mathrm{pH}$ середовища (з червоного на жовтий), Salmonella - чорні колонії з металевим блиском. Характерною особливістю наявності Staphylococcus epidermis були колонії жовтого кольору без зміни $\mathrm{pH}$ середовища.

На середовищі Кесслера у всіх зразках сиру відзначено зміну середовища, що свідчить про наявність БГКП (рис. 1-2). Лише у зразку 11 не відмічали помутніння, середовище залишилося прозоре (рис. 2). У зразку 2 спостерігали накопичення газу, у всіх решта помутніння середовища і осад. Очевидно, помутніння викликано ентеробактеріями (фекальні коліформні бактерії). При вивченні мікроскопії виявляли Грам (-) коки. У зразку 2 і 16 - Грам (-) палички.

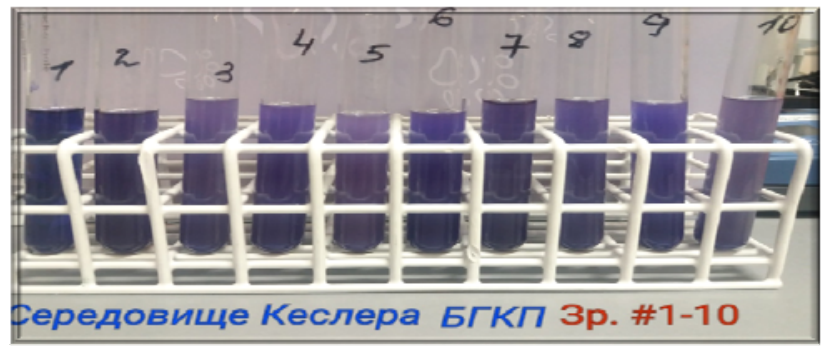

Рис. 1. Наявність БГКП у зразках сиру $1-10$

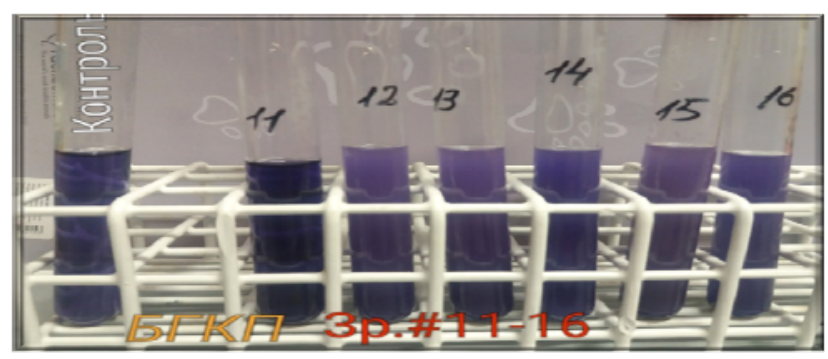

Рис. 2. Наявність БГКП у зразках сиру 11-16 


\section{Висновки}

Для розширення асортименту вітчизняних традиційних сирів необхідно проведення наукових досліджень щодо використання нетрадиційної для сироробної галузі сировини та впровадження системи управління якістю продукції на шляху для задоволення фізіологічних норм населення України в цьому продукті. Оцінка відповідності продукції вимогам якості може бути встановлена за результатами вибіркового аналізу зразків продукції, що перебувають в обігу, та має проводитися за комплексом органолептичних, фізико-хімічних та мікробіологічних показників.

Аналізуючи кислотність сирів, спостерігали, що вона була у сирі бринза - $260^{\circ} \mathrm{T}(\mathrm{pH} 4,9)$. За мікробіологічними показниками всі зразки характеризувалися наявністю патогенної мікрофлори. Зокрема у зразках 1,3, 5-9, 11-15 було виявлено наявність Staphylococcus aureus, у зразку 10 - Staphylococcus epidermis, у зразку 2 - бактерій роду Salmonella, у зразку 16 - Enterobacter aerogenes та у зразку 4 - плісень.

\section{References}

Basiuk, D.I. (2017). Vynnyi ta hastronomichnyi turyzm: hlobalni trendy ta lokalni praktyky: monohrafiia.Vinnytsia: PP "TD Edelveis i K” (in Ukrainian).

Bilyk O.Ia., \& Dronyk, H.V. (2014). Doslidzhennia biolohichnoi tsinnosti albuminovoho syru urda. Kharchova nauka i tekhnolohiia, 4(29), 36-40. doi: $10.15673 / 2073-8684.29 / 2014.33593$ (in Ukrainian).

Bilyk, O.Ya., Dronyk, G.V., Slyvka, N.B., \& Gutyj, B.V. (2017). Calculation of recipes and development of technological production schemes of albumin cheese "Urda" for industry. Scientific Messenger LNUVMBT named after S.Z. Gzhytskyj, 19(75), 65-71. doi:10.15421/nvlvet7513.

Gomez, M.J., Rodriguez, E., Gaya, P., \& Medina, M. (1999). Characteristics of Manchego cheese manufactured from raw and pasteurized ovine milk and with defined-strain or commercial mixed-strain starter cultures. Journal of Dairy Science, 82(8), 2300-2307. doi: $10.3168 /$ jds.S0022-0302(99)75478-0.
Halukh, B.I., Dronyk, H.V., \& Bilyk, O.Ya. (2010). Hutsulska brynza - korysnyi dlia zdorovia produkt. Silskyi hospodar, 3, 32-33 (in Ukrainian).

Irigoyen, A., Izco, J.M., Ibáñez, F.C., \& Torre, P. (2002). Influence of calf or lamb rennet on the physicochemical, proteolytic and sensory characteristics of an ewe's-milk cheese. International Dairy Journal, 12(1), 27-34. doi: 10.1016/S0958-6946(01)00147-9.

Milci, I.S., Goncu, A., Alpkent, Z., \& Yaygin, H. (2005). Chemical, microbiological and sensory properties of Halloumi cheese produced from, caprine and bouine milk. International Dairy Journal, 15(6), 625-630. doi: 10.1016/j.idairyj.2004.10.009.

Silva, R.C., Minim, V.P., Vidigal, M.C., Silva, A.N., Simiqueli, A.A., \& Minim, L.A. (2012). Sensory and Instrumental Consistency of Processed Cheeses. Journal of Food Research, 1(3), 204-213. doi: 10.5539/jfr.v1n3p204.

Slyvka, I., Tsisaryk, O., \& Musiy, L. (2017). The use of bacconcentrate Herobacterin in brine cheese technology. Food Science and Technology, 11(4), 81-89. doi: 10.15673/fst.v11i4.734 (in Ukrainian).

Slyvka, I., Tsisaryk, O., Dronyk, G., \& Musiy, L. (2018). Strains of lactic acid bacteria isolated from traditional Carpathian cheeses. Regulatory Mechanisms in Biosystems, 9(1), 62-68. doi: 10.15421/021808 (in Ukrainian).

Timchenko, O.V. (2017). Virulentnist kultur St. aureus, izolovanykh iz syroho moloka. Ahrarna nauka ta kharchovi tekhnolohii, 3(97), 242-247 (in Ukrainian).

Tsisaryk, O.I., Slyvka, I.M., \& Skulska, I.V. (2014). Tradytsii ta innovatsii u tekhnolohii brynzy. Zhurnal "Myr produktov. Molochnaia yndustryia", 4, 26-29 (in Ukrainian).

Turynskyi, V.M., Horlova, O.D., \& Tymofiiev, Ye.P. (2000). Tekhnolohiia vyrobnytstva ovechykh syriv v kolektyvnykh i fermerskykh hospodarstvak. Kyiv: BMT (in Ukrainian).

Vyshnevska, H.H., \& Tsehelnyk, A.O. (2012). Hastronomichni sviata ta festyvali yak turystychna atraktsiia. Heohrafiia ta turyzm, 55-61 (in Ukrainian).

Yashkina, O.I., \& Makovetska, D.O. (2017). Marketynhovi doslidzhennia vidnoshennia spozhyvachiv do novoi produktsii. Ekonomika ta upravlinnia pidpryiemstvamy, 9, 750-753 (in Ukrainian). 